This is the author's final, peer-reviewed manuscript as accepted for publication. The publisher-formatted version may be available through the publisher's web site or your institution's library.

\title{
Wilt-based irrigation in Kentucky bluegrass: effects on visual quality and irrigation amounts among cultivars
}

Jason D. Lewis, Dale J. Bremer, Steven J. Keeley, and Jack D. Fry

\section{How to cite this manuscript}

If you make reference to this version of the manuscript, use the following information:

Lewis, J. D., Bremer, D. J., Keeley, S. J., \& Fry, J. D. (2012). Wilt-based irrigation in Kentucky bluegrass: Effects on visual quality and irrigation amounts among cultivars. Retrieved from http://krex.ksu.edu

\section{Published Version Information}

Citation: Lewis, J. D., Bremer, D. J., Keeley, S. J., \& Fry, J. D. (2012). Wilt-based irrigation in Kentucky bluegrass: Effects on visual quality and irrigation amounts among cultivars. Crop Science, 52(4), 1881-1890.

Copyright: @ Crop Science Society of America

Digital Object Identifier (DOI): doi:10.2135/cropsci2012.01.0033

Publisher's Link: https://www.crops.org/publications/cs/abstracts/52/4/1881

This item was retrieved from the K-State Research Exchange (K-REx), the institutional repository of Kansas State University. K-REx is available at http://krex.ksu.edu 
Wilt-Based Irrigation in Kentucky bluegrass:

$7 \quad{ }^{1}$ Dept. of Horticulture \& Crop Science, California Polytechnic State University, San Luis

8 Obispo, CA, 93407; ${ }^{2}$ Dept. of Horticulture, Forestry \& Recreation Resources, 2021

9 Throckmorton Plant Sciences Center, Manhattan, KS 66506. Contribution no. 11-254-J from the 10 Kansas Agricultural Experiment Station.

11

12 Received ___ Corresponding author email: jlewis07@calpoly.edu

13

14

15 Abbreviations: ET, evapotranspiration, KBG, Kentucky bluegrass, NTEP, National Turfgrass

16 Evaluation Program, SAS, Statistical Analysis Software. 


\section{Abstract}

2 A critical challenge facing the turf industry is increasingly limited water supplies. Identifying

3 cultivars that use less water while maintaining acceptable quality may mitigate irrigation

4 demands. Our objectives were to identify Kentucky bluegrass (Poa pratensis L.) (KBG) cultivars

5 and phenotypic groups that maintained better visual quality with less water. Thirty bluegrass

6 selections were evaluated in a 2-year field study under a rainout shelter near Manhattan, KS,

7 USA. Irrigation $(2.5 \mathrm{~cm})$ was applied when $>50 \%$ of a plot exhibited visible wilt symptoms.

8 Visual quality was rated daily. Average irrigation applications ranged widely from $23.3 \mathrm{~cm}$

9 (mean=2.2 $\mathrm{mm} \mathrm{d}^{-1}$ ) in Bedazzled to $44.9 \mathrm{~cm}$ (mean=4.2 $\mathrm{mm} \mathrm{d}^{-1}$ ) in Kenblue, and days to wilt

10 between irrigations ranged from $6.4 \mathrm{~d}$ in Kenblue to $13.1 \mathrm{~d}$ in Cabernet. Visual quality averaged

11 at or slightly below 6.0, defined as "minimally acceptable”, but this may be adequate when water

12 conservation is a priority and some dormancy is tolerable; irrigation at $<50 \%$ wilt is

13 recommended for improved quality. Based on statistical range tests, 15 of the 30 cultivars were

14 grouped as both receiving the least water and having the greatest visual quality. Overall, the

15 Compact America and Mid-Atlantic KBG groups exhibited the greatest days to wilt and received

16 the least water. Results suggest that Compact America and Mid-Atlantic phenotypes have the

17 greatest potential for integrating reduced water inputs with maintenance of acceptable visual

18 quality. 
1 One of the most important challenges facing the turfgrass industry is a decreasing supply of

2 water for irrigation. Consequently, reducing irrigation inputs and improving turfgrass resistance

3 to drought stress are important objectives. Turf managers commonly face drought, which can

4 occur throughout the United States. The Environmental Institute for Golf recently reported that

5 future water availability is a serious issue in the western United States, that there is a lack of data

6 on water use in many states, and that state and local drought restrictions may be imposed on turf

7 managers with no regard for damage to turfgrasses (Beard and Kenna, 2008). Nevertheless,

8 clients and the public express their displeasure when turfgrass quality is reduced during irrigation

9 restrictions.

In 2005, a NASA-funded study determined that turfgrass already covered an area three

11 times greater than any other irrigated crop in the United States (Milesi et al., 2005). Furthermore,

12 urban expansion in the US is projected to continue its rapid increase (Alig et al., 2004). Because

13 turfgrass acreage is likely to increase with urban expansion, demand for water for the irrigation

14 of turfgrass will also increase substantially. One strategy to mitigate irrigation demands for

15 turfgrass is to identify cultivars that maintain better quality with less water.

16 Kentucky bluegrass (KBG) is one of the most widely used turfgrasses for home lawns,

17 golf courses, parks, and athletic fields in temperate climates (Turgeon, 2002; Lyman et al.,

18 2007). Kentucky bluegrass often goes dormant under drought conditions, which severely

19 decreases its visual quality and function. Although information is available on turfgrass quality

20 among well-watered cultivars of KBG (i.e., National Turfgrass Evaluation Program [NTEP]

21 trials, 2006; Morris, 2000), more information is needed on cultivars that maintain relatively

22 better quality under reduced irrigation and field conditions. 
Significant variation in water use has been observed among cultivars of KBG in

2 experiments conducted in growth chambers, greenhouses, and lysimeter-based field studies

3 (Steinegger et al., 1980; Shearman, 1986; Ebdon and Kopp, 2004; Ebdon and Petrovic, 1997,

4 1998; Ebdon et al., 1998a, 1998b; Abraham et al., 2004). Although growth chambers and

5 greenhouses have the advantage of more controlled environments, they do not necessarily

6 represent water use in the field where conditions are more variable. Lysimeters are used in the

7 growth chamber, greenhouse, and some field studies, but they may restrict soil volumes for root

8 growth, result in higher root temperatures than in surrounding ambient soils, and alter

9 physiological properties of turfgrasses (e.g., leaf area, above and below ground biomass density),

10 all of which may impact water use (Bremer, 2003). Non-lysimeter based field studies (i.e., turf

11 grown in field plots without the limitations of lysimeters) that integrate water use in turfgrasses

12 over several weeks, months, or years may be useful because they represent conditions more

13 typical of lawns or golf courses.

14 Field studies investigating drought tolerance in KBG have been conducted by completely

15 withholding irrigation and measuring plant responses (Keeley and Koski, 2001; Richardson et

16 al., 2008, 2009; Merewitz et al., 2010). Richardson et al. (2009) concluded that KBG had wide

17 variability in drought tolerance, and that broad screening could result in water conservation.

18 Similarly, Richardson et al. (2008) identified several cultivars including Mallard, Moonlight,

19 Prosperity, SR 2284, Brilliant, and Diva, as having better drought tolerance among 50 KBG

20 cultivars screened; drought tolerance was defined as the number of days until a cultivar reached

$2150 \%$ green tissue, using digital image analysis. Merewitz et al. (2010) also reported wide

22 variability in drought tolerance among a number of KBG cultivars and hybrid bluegrasses (KBG 
1 x Texas bluegrass [P. arachnifera Torr. x P. pratensis]), with one hybrid demonstrating greater

2 drought tolerance than the other entries.

3 While field studies that withhold irrigation completely are useful, they represent the

4 opposite extreme of well-watered conditions. A legitimate question is whether the quality of

5 some KBG cultivars is better than others under less than well-watered conditions, but where

6 some irrigation is allowed. This is similar to deficit irrigation, which has been determined as

7 beneficial by a number of turfgrass researchers; one benefit has been the maintenance of good

8 quality KBG with reduced irrigation (Minner, 1984; Gibeault et al., 1985; Fu et al., 2004). Using

$950 \%$ deficit irrigation in semi-arid Utah, greater percent green cover was found in several

10 accessions and old U.S. cultivars of KBG, which indicated KBG has potential to maintain

11 acceptable green cover under reduced water inputs (Bushman et al., 2012). The water-deficit

12 approach, however, requires a reference ET (100\%) to calculate deficit irrigation amounts and

13 therefore, is not practical to the typical homeowner or golf course superintendent (e.g., for KBG

14 in their roughs). A more realistic approach may be wilt-based irrigation, or waiting until drought

15 stress is visible before irrigating the turfgrass. To our knowledge, this approach has not been

16 used to evaluate long-term effects on visual quality and irrigation amounts in KBG.

17 Kentucky bluegrasses have been classified into phenotypic groups, which may be useful

18 in predicting drought tolerance (Murphy et al., 1997; Bonos et al., 2000). Because cultivar

19 turnover is rapid in the turfgrass industry, determining the relative irrigation requirements of

20 phenotypic groups may enable researchers to predict irrigation requirements of cultivars not

21 included in any particular study. Keeley and Koski (2001) investigated visual quality and leaf

22 firing during field dry-downs of 22 to 33 days of 15 cultivars of KBG, representing various KBG

23 phenotypic groups. Those authors reported that dehydration avoidance rankings from high to low 
1 were: Mid-Atlantic > Bellevue > BVMG > Common. In contrast, Richardson et al. (2008) did

2 not find any clear trends in drought tolerance, as measured by days to $50 \%$ green cover, among

3 phenotypic groups of KBG. Beyond the latter studies, few have investigated relative drought

4 tolerance among phenotypic groups of KBG in a field setting.

$5 \quad$ Our objectives were to identify KBG cultivars and phenotypic groups that maintain better

6 visual quality with less irrigation, using wilt-based irrigation. We hypothesized that if visual

7 quality was good at the beginning of the season, we could maintain minimally acceptable quality

8 in KBG (e.g., for a moderately-maintained golf course rough or a home lawn with in-ground

9 sprinklers) by irrigating when at least $50 \%$ of a given cultivar showed signs of wilt. Two hybrid

10 bluegrasses were also included in the study.

\section{Materials and Methods}

\section{Field Study}

14 Data were collected from 19 June to 1 Oct. 2007 (105 d), and 22 June to 7 Oct. 2009 (108

15 d). Data were not collected in 2008 because of a bluegrass billbug (Sphenophorus parvulus

16 Gyllenhal) infestation. The plots were under an automated rainout shelter (12 by $12 \mathrm{~m}$ ) at the

17 Rocky Ford Turfgrass Research Center near Manhattan, KS (39¹3’53” N, 96³4’51”W).

18 Manhattan lies in the U.S. transition zone, which covers 480 to $1120 \mathrm{~km}$ north to south between

19 the northern regions where cool-season grasses are adapted and the southern regions where

20 warm-season grasses are adapted (Dunn and Diesburg, 2004). The rainout shelter rested north of

21 the plot area but automatically covered the research plots as precipitation began and retracted $1 \mathrm{~h}$

22 after it ceased. The soil at the site was a Chase silt loam (fine, smectitic, mesic Aquertic

23 Argiudoll). 
Turfgrasses in the study included 28 KBG cultivars and two hybrid bluegrasses (Table 1).

2 Commercially available cultivars of KBG were selected to include representatives from major

3 KBG phenotypic groups (Murphy et al., 1997; Bonos et al., 2000). Additionally, because visual

4 quality was of interest in our research, cultivars were selected based on performance in the NTEP

5 trials (National Turfgrass Evaluation Program, 2001). The mean quality of cultivars in the

6 Compact, Compact Midnight, and Compact America groups was generally among the top third

7 among all NTEP entries. In the remainder of groups, representatives with mean quality in the top

8 third were not often available. Therefore, the best performing representatives were typically

9 selected from within each group. Previous research has indicated that Compact America and

10 Mid-Atlantic types are more drought resistant than other phenotypic groups including the

11 Common types (Keeley and Koski, 2001; Kraft and Keeley, 2005). Because only two cultivars

12 each from the Mid-Atlantic (Cabernet and Eagleton) and Common (Kenblue and Wellington)

13 groups were included in the 2001 KBG NTEP trial, Preakness and Park were added to increase

14 the size of the Mid-Atlantic and Common groups, respectively.

15 Plots were arranged in a randomized complete block design with three replications.

16 Ninety plots measuring 1.13 by $1.22 \mathrm{~m}$ were bordered by metal edging (10 cm depth) to prevent

17 lateral soil water movement. Before seeding, the plot area was treated with dazomet (tetrahydro-

18 3,5-dimethyl-2H-1,3,5-thiadiazine-2-thi-one) at $575 \mathrm{~kg}$ a.i. ha ${ }^{-1}$ to kill vegetation and insect,

19 weed, and pathogen pests. On 19 Sept. 2006, plots were seeded at $100 \mathrm{~kg} \mathrm{ha}^{-1}$ pure live seed.

20 Starter fertilizer (18-20-0) was applied at the rate of $50 \mathrm{~kg} \mathrm{~N} \mathrm{ha}^{-1}$ and plots were covered with a

21 seed germination blanket (Futerra F4 Netless, Profile Products LLC, Buffalo Grove IL) to

22 prevent movement of seed across plots from wind or water. Plots were irrigated several times

23 daily to maintain a moist seedbed during establishment. 
1 The plots were well watered until 19 June 2007. Thereafter, turfgrass quality and drought stress

2 were evaluated daily; generally, this was conducted by the same person and in mid-afternoon.

3 The evaluator was trained by experienced visual quality evaluators using materials from a NTEP

4 Workshop.

5 Turfgrass quality evaluations, based on color, density, and uniformity of the canopies,

6 were made using a visual rating scale of 1 to 9 , with 1 = brown turf, $6=$ minimally acceptable for

7 home lawn or golf course rough, and 9 = optimum turf (Skogley and Sawyer, 1992).

8 Drought stress was defined as the turf displaying wilting, failure of the canopy to remain

9 upright after foot traffic, and a general darkening color of the turf. When $50 \%$ or more of a plot

10 displayed drought stress, it was irrigated. Because changes in drought stress were sometimes

11 rapid from day to day, particularly under conditions of high temperatures, it was not unusual for

12 irrigation to be applied when greater than $50 \%$ of a plot (e.g., up to 70 or $80 \%$ ) displayed drought

13 stress.

14 To maintain a practical approach, the same amount of water was applied to plots at each

15 irrigation. The amount of water applied each time was $2.5 \mathrm{~cm}$, which is a standard

16 recommendation for homeowners (Fagerness, 2001); each water application was then recorded

17 for the plot. In theory, $2.5 \mathrm{~cm}$ filled the surface $10 \mathrm{~cm}$ to field capacity for our soil texture.

18 Because of negative matric potential in dry soil throughout the profile, however, water likely

19 penetrated deeper than $10 \mathrm{~cm}$. In KBG, 90 to $96 \%$ of roots are in the upper 20 to $30 \mathrm{~cm}$ and the

20 greatest root density is undoubtedly nearer the surface (Suplick-Plonse and Qian, 2005; Su et al.,

21 2008).

Water was applied by hand through a fan spray nozzle attached to a hose; a meter (Model

23 03N31, GPI, Inc., Wichita, KS) was attached to ensure proper application amount. The dry- 
1 down cycles continued until 1 Oct. 2007, after which plots were thoroughly watered to allow for

2 recovery. The experiment was repeated in 2009; the dry-down started on 22 June 2009, and was

3 completed 7 Oct. 2009.

4

5 Plot Maintenance

6 Plots were mown weekly with a rotary mower at $7.6 \mathrm{~cm}$. Imidacloprid (1-[(6-chloro-3-

7 pyridinyl)methyl 3 (2-chloro-3,3,3-trifluoro-1-propenyl)-2,2-dimethylcyclopropanecarboxylate)

8 was applied at $0.12 \mathrm{~kg}$ a.i. ha ${ }^{-1}$ to control billbug grubs and white grubs (Cyclocephala lurida

9 Bland) on 1 May 2007 and 4 May 2009. Azoxystrobin ((methyl(E)-2-\{2-[6-(2-cyanpphenoxy)

10 pyrimidin-40yloxy]phenyl\}-3-methoxyacrylate)) was applied at $0.61 \mathrm{~kg}$ a.i. ha ${ }^{-1}$ on 4 June 2007

11 and 9 June 2009 for summer patch control (Magnoporthe poae Landschoot \& Jackson). The

12 herbicides carfentrazone-ethyl (Ethyl $\alpha, 2-$ dichloro-5-[4(difluoromethyl)-4,5-dihydro-3-methyl-5-

13 oxo-1H-1,2,4-trizol-1-yl]-4-fluorobenzenepropanoate) $\left(0.03 \mathrm{~kg}\right.$ a.i. ha $\left.{ }^{-1}\right)+$ 2,4-D [2-ethylhexyl

14 ester (2,4-dichlorophenoxyacetic acid] (1.29 kg a.i. ha $\left.{ }^{-1}\right)+$ Mecoprop-p acid [(+)-R-2-(2-methyl-

15 4-chlorophenoxy)propionic acid] (0.27 kg a.i. ha $\left.{ }^{-1}\right)+$ dicamba acid (3,6-dichloro-o-anisic acid)

16 (0.08 kg a.i. ha ${ }^{-1}$ ) were applied on 16 Mar. 2007, 20 Oct. 2007, and 15 Mar. 2009 for broadleaf

17 weed control. Applications of dithiopyr [S,S'-dimethyl 2-(difluoro-methyl)-4-(2-methylpropyl)-

18 6-(trifluoromethyl)-3,5-pyridin-edicarbothioate] were made at $0.58 \mathrm{~kg}$ a.i. ha ${ }^{-1}$ on 27 May 2007

19 and 15 May 2009 to control annual grassy weeds.

20 All plots were fertilized with urea (46-0-0) at $50 \mathrm{~kg} \mathrm{~N}$ ha $^{-1}$ on 15 April 2007; $25 \mathrm{~kg} \mathrm{~N} \mathrm{ha}^{-1}$

21 on 1 June 2007; $50 \mathrm{~kg} \mathrm{~N} \mathrm{ha}^{-1}$ on 5 Oct. 2007; $25 \mathrm{~kg} \mathrm{~N}$ ha $^{-1}$ on 24 April 2009; $25 \mathrm{~kg} \mathrm{~N}$ ha $^{-1}$ on 24

22 May 2009; $38 \mathrm{~kg} \mathrm{~N} \mathrm{ha}^{-1}$ on 8 June 2009. A polymer-coated urea (43-0-0, POLYON, Agrium

23 Technologies, Loveland, CO) was applied on 24 April 2009 at $75 \mathrm{~kg} \mathrm{~N} \mathrm{ha}^{-1}$. After fertilizations, 
1 plots were irrigated with about $15 \mathrm{~mm}$ of water to incorporate fertilizer into the soil and reduce

2 ammonia volatilization (Bowman et al., 1987).

4 Data Analysis

Water applications to plots were compared with reference evapotranspiration (ET), which

6 was calculated with the FAO-56 Penman-Monteith equation using local data obtained from the

7 Kansas State Univ. Weather Data Library (Allen et al., 1998). Among KBG cultivars and

8 phenotypic groups, differences in water application amounts, days to wilt between irrigations,

9 days until visual quality of each cultivar declined to less than six (all cultivars declined to $<6$ in

10 both years), and average visual quality were analyzed by the mixed models procedure of the

11 statistical analysis software (SAS), and means were separated using Fisher's protected least

12 significant difference (LSD) at $P=0.05$ (SAS Institute, 2002).

13 Planned orthogonal contrasts were conducted $(P=0.05)$ to evaluate differences in water

14 applications, visual quality, days to wilt, and days until quality declined below six between

15 Compact America and all other groups, between Mid-Atlantic and the other groups, excluding

16 Compact America, and between Common and the remaining groups, excluding Compact

17 America and Mid-Atlantic. Orthogonal contrasts were conducted using the estimate option in the

18 mixed model procedure of SAS. Only phenotypic groups with three or more cultivars

19 represented were included in the contrast statements.

\section{Results and Discussion}

22 Total Water Applied and Days to Wilt between Irrigation Cycles 
There was a cultivar and a year effect for the total amount of water applied and for days

2 to wilt between irrigation cycles. When compared across years, total water application among

3 bluegrasses averaged $36.7 \mathrm{~cm}$ in 2007 and $28.8 \mathrm{~cm}$ in 2009 . When averaged by week, total water

4 applications were $2.5 \mathrm{~cm}$ in 2007 and $1.9 \mathrm{~cm}$ in 2009, a difference of $6.0 \mathrm{~mm} \mathrm{wk}^{-1}$. Days to wilt

5 between irrigation cycles averaged $8.0 \mathrm{~d}$ in 2007 and $10.2 \mathrm{~d}$ in 2009 . There was no interaction

6 between year and cultivar effects, however, so total water applied to the cultivars and days to

7 wilt between irrigation cycles are presented in order of their respective averages between 2007

8 and 2009 (Table 2).

$9 \quad$ Water applications during the two-year study ranged widely from $23.3 \mathrm{~cm}\left(2.2 \mathrm{~mm} \mathrm{~d}^{-1}\right)$ in

10 Bedazzled to $44.9 \mathrm{~cm}\left(4.2 \mathrm{~mm} \mathrm{~d}^{-1}\right)$ in Kenblue (Table 2). In Bedazzled, Apollo, Cabernet, and

11 Unique, $25 \mathrm{~cm}\left(2.3 \mathrm{~mm} \mathrm{~d}^{-1}\right)$ of water or less was applied, which was significantly less than

12 Kenblue, Blue Knight, Wellington, Moonlight, Baron, Diva, Midnight II, Touchdown,

13 Shamrock, and Blue Velvet; in the latter 10 cultivars, $>35 \mathrm{~cm}\left(>3.3 \mathrm{~mm} \mathrm{~d}^{-1}\right)$ of water was

14 applied. However, there were no statistical differences among the 15 cultivars that received the

15 least amount of water.

16 Days to wilt between irrigations, which was roughly inverse the amount of water applied

17 ( $\mathrm{r}=-0.91)$, ranged from $6.4 \mathrm{~d}$ in Kenblue to $13.1 \mathrm{~d}$ in Cabernet, a difference of nearly one week

18 (Table 2). Days to wilt was greater in Cabernet, Bedazzled, Unique, and Apollo (11.9 to $13.1 \mathrm{~d}$ )

19 than in the 18 bluegrasses with the least days to wilt (6.4 to $9.0 \mathrm{~d}$ ). These intervals provide the

20 practitioner with an estimate of irrigation frequency required to maintain the various KBGs at a

21 performance level similar to this study, at least in the transition zone of the U.S. In addition to

22 less frequent irrigation, cultivars with more days to wilt have a greater likelihood of receiving 
1 rainfall between irrigations; this could result in further water conservation and reduced irrigation

2 costs.

3 The overall wide ranges in water applications and days to wilt in this study may have

4 been related to differences in ET rates among cultivars. For example, ET rates of 3.86 to 6.34

$5 \mathrm{~mm} \mathrm{~d}^{-1}$ were observed among 20 well-watered KBG cultivars in a growth chamber study

6 (Shearman, 1986). Presumably, cultivars with greater ET rates would deplete soil moisture and

7 wilt faster than cultivars with low ET rates. Ebdon and Kopp (2004), however, reported

8 negligible differences in leaf firing or wilt between 12 high- and low-ET KBG genotypes in a

9 greenhouse study, suggesting ET rates under well-watered conditions are not good indicators of

10 drought survival. Those authors concluded that deeper rooting probably mitigated drought

11 symptoms in high ET grasses. Thus, differences in rooting depth among cultivars may also have

12 impacted days to wilt and water applied in our study.

13 The wide range of water required to alleviate drought symptoms also suggests differences

14 in drought tolerances among cultivars. Indeed, field investigations of up to $50 \mathrm{KBG}$ cultivars and

15 hybrid bluegrasses revealed wide variations in drought tolerance and in recovery from drought

16 (Richardson et al., 2008, 2009). In our study, Diva ranked $6^{\text {th }}$ numerically for greatest water

17 applied $(38.1 \mathrm{~cm})$ and Midnight was midway in the water-applied rankings $(31.8 \mathrm{~cm})$ (Table 2).

18 This does not appear to correlate well with the results of Richardson et al. (2008), who reported

19 Diva and Midnight as having good drought tolerance; in their study drought tolerance was

20 measured using digital image analysis as the number of days until a cultivar reached $50 \%$ green

21 tissue. Differences in objectives and hence, methodologies between studies probably explain this

22 apparent disparity and indicates that screening for KBG cultivars that maintain quality with less

23 water, such as in our study, may not result in selection of cultivars with better drought tolerance. 
The average cumulative grass reference crop ET for the two years, as calculated with the

2 FAO-56 equation (Allen et al., 1998), was $50.2 \mathrm{~cm}\left(4.7 \mathrm{~mm} \mathrm{~d}^{-1}\right)$. All cultivars received less than

3 that, and the cultivar that received the least water (Bedazzled) was less than half (46\%) of that

4 predicted by the FAO-56 (Table 2); the FAO-56 equation assumes a 12-cm grass canopy grown

5 under non-limiting soil moisture, which contrasts with our shorter grass canopy and limiting soil

6 moisture.

7 Notably, all cultivars in the phenotypic group Mid-Atlantic (Cabernet, Eagleton, and

8 Preakness) and four of five in the Compact America group (Apollo, Bedazzled, Kingfisher, and

9 Unique) were among the 15 cultivars that received the least amount of water. When averaged

10 over all cultivars within each phenotypic group, $27.3 \mathrm{~cm}\left(2.56 \mathrm{~mm} \mathrm{~d}^{-1}\right)$ of water was applied to

11 Compact America types and $27.7 \mathrm{~cm}\left(2.60 \mathrm{~mm} \mathrm{~d}^{-1}\right)$ to Mid-Atlantic types, which was less than

12 the Common, Compact, and Compact Midnight groups (Table 3). Days to wilt was also greater

13 in Mid-Atlantic and Compact America than in all other groups. Greater days to wilt may be

14 related to a combination of a deep root system and lower ET rates (Ebdon and Petrovic, 1997;

15 Brooks Gould, 2004). Mid-Atlantic types have lower ET because of their growth characteristics

16 that promote high canopy resistance and low leaf area, both of which reduce ET (Ebdon and

17 Petrovic, 1998). Such canopy characteristics, which are also found in Compact America types,

18 include decumbent growth habit, slow leaf growth rates and high shoot and leaf densities.

Two of the three cultivars in the Common group (Kenblue and Wellington) ranked high

20 in the amount of water applied, at 44.9 and $41.9 \mathrm{~cm}\left(4.2\right.$ and $\left.3.9 \mathrm{~mm} \mathrm{~d}^{-1}\right)$, respectively (Table 2).

21 The last Common entry, Park, required $33.4 \mathrm{~cm}\left(3.1 \mathrm{~mm} \mathrm{~d}^{-1}\right)$ and was in the middle of the

22 rankings (Table 2). As a group, the Common types received more water $\left(40.1 \mathrm{~cm}, 3.8 \mathrm{~mm} \mathrm{~d}^{-1}\right)$ 
1 than all other groups except Compact (Table 3), which may have been related to higher ET rates

2 in Common types (Ebdon and Petrovic, 1997).

3 Orthogonal contrasts revealed that the Compact America group received less water and

4 exhibited greater days to wilt than the other phenotypic groups (Table 3). Similarly, the Mid-

5 Atlantic group received less water and exhibited greater days to wilt than the other types,

6 excluding Compact America. The contrast between the Common group and the other phenotypic

7 groups, excluding Compact America and Mid-Atlantic to retain orthogonality, revealed that the

8 Common group received greater amounts of water but exhibited similar days to wilt.

$9 \quad$ Our results are supported by the findings of Keeley and Koski (2001), who reported

10 dehydration avoidance rankings among KBG phenotypic groups from high to low as Mid-

11 Atlantic $>$ Bellevue $>$ BVMG $>$ Common. In another KBG study, however, no clear trends were

12 found relating phenotypic groups with drought tolerance (Richardson et al., 2008). In the latter

13 study, the authors did recommend the use of Moonlight and Diva (Compact types) and Mallard,

14 SR 2284, and Brilliant (Compact America types) for future breeding efforts for drought

15 tolerance, since those cultivars performed well in the drought study.

17 Visual Quality

18 There was a cultivar effect and a year effect for the rankings of days until visual quality

19 declined to less than six, and a cultivar effect for average visual quality. The days until visual

20 quality declined to less than six, averaged across all cultivars, was 25.2 days in 2007 and 32.8

21 days in 2009. In 2007, the faster decline in mean visual quality among the 30 bluegrasses was

22 primarily an artifact of low outliers, the Common types. Visual quality was well below six in all

23 three Common types from the beginning of the study in 2007, while all cultivars were above six 
1 at the beginning of 2009 (Fig. 1). There was no interaction between year and cultivar in days

2 until quality declined to less than six, however, so rankings of cultivars are presented as their

3 respective averages over 2007 and 2009 (Table 4).

$4 \quad$ In all bluegrasses and in both years, visual quality declined to below six (Fig. 1). This

5 indicates waiting until 50\% wilt to apply irrigation was insufficient to maintain acceptable visual

6 quality in KBG, at least for homeowners or superintendents who desire a moderate standard of

7 quality in the stressful climate of the transition zone. Perhaps visual quality could have been

8 maintained at acceptable levels by applying water when only $25 \%$ of the plot exhibited

9 symptoms of drought stress. Further research may be required to determine the optimum timing

10 for irrigating turfgrass to maintain acceptable quality for moderately managed turfgrass with

11 minimal amounts of water. Our method may be appropriate, however, for the typical homeowner

12 with no in-ground sprinklers or superintendents with low-maintenance roughs on their golf

13 courses, or where the primary concern is water conservation and some dormancy is acceptable.

14 With the exception of Kenblue, Park, and Eagleton on one date in Aug. 2007, visual quality in all

15 bluegrasses remained above four, and recovery was rapid in the fall after resuming irrigation

16 (data not shown).

17 Although visual quality declined to less than six in all cultivars, the time required to do so

18 ranged widely from $8.1 \mathrm{~d}$ in Kenblue to $44.8 \mathrm{~d}$ in Blue Velvet (Table 4). The decline was slower

19 in Blue Velvet, Award, Midnight, Cabernet, Unique, and New Destiny (36 to 44.8 d) than in

20 Park, Baron, Wellington, and Kenblue (8.1 to 14.2 d). Thus, four of five cultivars in the Compact

21 Midnight group maintained quality longer than all cultivars in the Common group. This is

22 reflected in the group rankings, in which Compact Midnight types remained above a quality of

23 six for longer than the Common as well as the BVMG types (Table 5). Orthogonal contrasts also 
1 revealed the Common group declined to less than six faster than all other groups (again,

2 excluding Compact America and Mid-Atlantic types to retain orthogonality).

3 Average visual quality rankings of the bluegrasses ranged from 4.98 in Kenblue to 6.17

4 in Blue Velvet, with Blue Velvet, Bartitia, Preakness, and Nu Destiny averaging greater than

5 Wellington, Park, and Kenblue (Table 4). No differences were observed, however, among the 25

6 cultivars with the greatest visual quality. While these values seem low, rankings below six are

7 not unusual for KBG in field trials of NTEP, which ranged from 3.8 to 6.3 for medium to high

8 input cultivars at various locations across the United States (National Turfgrass Evaluation

9 Program, 2006). Also, past NTEP trials in Kansas have typically had lower mean visual quality

10 levels than comparable trials in other US locations (National Turfgrass Evaluation Program,

$112000,2006)$.

12 Among phenotypic groups, all were similar in visual quality with the exception of the

13 Common group, which was lower (Table 5). The three common entries of Wellington, Park, and

14 Kenblue had the lowest numeric quality ratings of 5.40, 5.13, and 4.98, respectively (Table 4).

15 Orthogonal contrasts between the Common group and the remaining groups, excluding the

16 Compact America and Mid-Atlantic, revealed that visual quality was lower in the Common

17 group. However, orthogonal contrasts revealed no differences in visual quality between the

18 Compact America group and all other phenotypic groups, or between the Mid-Atlantic group and

19 the remaining groups, excluding Compact America.

21 Relationships between Water Requirement and Visual Quality

22 The objective of the field study was to identify cultivars and phenotypic groups that

23 retained acceptable visual quality with a minimum amount of water. Ideally, the cultivars or 
1 groups requiring the least amount of water would also have the highest visual quality. To better

2 illustrate the relationships between irrigation applied and visual quality among the cultivars in

3 our study, we created a scatter biplot (Fig. 2). In this way we identified general trends among

4 cultivars that required the least amount of water but also had the highest visual quality. In Figure

5 2, cultivars with the most favorable characteristics (i.e., low water applications and high visual

6 quality) appear in the lower right section.

7 In general, irrigation applications were greater in bluegrasses with poorer quality

$8 \quad(\mathrm{r}=-0.39, P<0.0001)$ (Fig. 2). Ebdon and Petrovic (1997) reported a similar pattern of strong

9 negative correlation between KBG turf quality and ET rates $(\mathrm{r}=-0.51, P<0.001, \mathrm{n}=59)$. Those

10 authors concluded this correlation resulted from improved cultivars with morphological

11 properties that both enhanced turf quality and reduced ET, such as compact or dwarfed growth

12 habits, horizontal leaf orientation, and greater shoot density. In the study by Ebdon and Petrovic

13 (1997), however, ET was measured under controlled environments and turf quality was derived

14 from numerous NTEP locations. Our current study shows more direct evidence between water

15 requirements and turf performance in the field.

16 All 15 bluegrasses with the lowest water applications were also ranked among those with

17 the highest visual quality (Tables 2 and 4). The amount of water applied to these 15 cultivars

18 with superior turf quality was also below the mean water applied to all 30 bluegrasses (Fig. 2).

19 Similarly, visual quality in 12 of the 15 bluegrasses that received the least water was greater than

20 the mean of all 30 bluegrasses, although all 15 were statistically similar.

21 All three Mid-Atlantic types, four of the five Compact America types, and none of the

22 Common types were included in the 15 bluegrasses with the lowest water applications and

23 superior quality. No other clear patterns were evident among phenotypic groups in the 15 best 
1 performers. Bushman et al. (2012) reported that out of 289 entries of $P$. pratensis, two of three

2 Compact America entries (Brilliant and Langara) and the only Mid-Atlantic entry (Eagleton) in

3 their study showed promise of further evaluation for drought tolerance and stay-green behavior.

4 One hybrid bluegrass in our study, Thermal Blue Blaze, fell within the group of 15 receiving the

5 least water but not the other (Longhorn). This supports results from other research, including at

6 the same site as the current study, that indicates hybrids have negligible advantage over KBGs in

7 tolerating drought stress (Bremer et al., 2006; Su et al., 2007, 2008, 2009; Richardson et al., 8 2008, 2009).

9 In contrast to the 15 top performers, six cultivars were ranked within the group that 10 received the most water and had the lowest visual quality (Tables 2 and 4; Fig. 2). Those six

11 cultivars, which included Kenblue, Wellington, Midnight II, Baron, Diva, and Shamrock, had 12 neither the high visual quality nor low water requirement traits we were screening for in this 13 study.

15 Conclusions

16 Results indicated that KBG cultivar selection had significant impacts on water 17 requirements and visual quality ratings. Among cultivars, differences in seasonal water 18 applications were as great as $21.6 \mathrm{~cm}$ and differences in days to $50 \%$ wilt were as great as $6.7 \mathrm{~d}$. 19 Based on statistical range tests, only 15 of the 30 cultivars were in the group that both received 20 the least water and had the greatest visual quality. Results indicated that, under conditions similar

21 to those in our study, KBG in the Compact America and Mid-Atlantic phenotypic groups can be

22 selected for their lower irrigation requirements without sacrificing visual quality, and types from

23 those two groups may represent the best selections for breeding efforts to achieve such goals. 


\section{Acknowledgements}

3 This research was funded by United States Golf Association (USGA), Turfgrass

4 Producers International (TPI), and the Kansas Turfgrass Foundation. The technical assistance of 5 Tony Goldsby was greatly appreciated. 


\section{References}

2 Abraham, E.M., B. Huang, S.A. Bonos, and W.A. Meyer. 2004. Evaluation of drought resistance

3 for Texas bluegrass, Kentucky bluegrass, and their hybrids. Crop Sci. 44:1746-1753.

4 Alig, R.J., J.D. Kline, and M. Lichtenstein. 2004. Urbanization on the US landscape: Looking

$5 \quad$ ahead in the 21st century. Landscape and Urban Planning 69:219-234.

6 Allen, R.G., L.S. Pereira, D. Raes and M. Smith. 1998. Crop evapotranspiration - guidelines for

7 computing crop water requirements - FAO irrigation and drainage paper 56. FAO - Food and

8 Agriculture Organization of the United Nations, Rome, Italy.

9 Beard, J.B., and M.P. Kenna (eds.) 2008. Water quality and quantity issues for turfgrasses in

10 urban landscapes. Council for Agriculture Science and Technology, Ames, IA, USA.

11 Bonos, S.A., W.A. Meyer, and J.A. Murphy. 2000. Classification of Kentucky bluegrass

12 genotypes grown as spaced-plants. HortScience 35:910-913.

13 Bowman, D.C., J.L. Paul, and W.B. Davis. 1987. Reducing ammonia volatilization from

14 Kentucky bluegrass turf by irrigation. HortScience 22:84-87.

15 Bremer, D.J. 2003. Evaluation of microlysimeters used in turfgrass evapotranspiration studies

16 using the dual-probe heat-pulse technique. Agron. J. 95:1625-1632.

17 Bremer, D.J., K. Su, S.J. Keeley, and J.D. Fry. 2006. Performance in the transition zone of two

18 hybrid bluegrasses compared with Kentucky bluegrass and tall fescue.[Online]. Available at

19 http://www.plantmanagementnetwork.org/ats/. (verified 25 June, 2010). Applied

20 Turfgrass Sci.doi.10.1094/ATS-2006-0808-01-RS

21 Brooks Gould, A. (ed.) 2004. Rutgers Turfgrass Proc. New Jersey Turfgrass Expo. 7-9 Dec.

22 2004. New Jersey Turfgrass Assoc. Atlantic City, New Jersey. 
1 Bushman, S.B., B.L. Waldron, J.G. Robins, K. Bhattarai, and P. G. Johnson. 2012. Summer

2 percent green cover among Kentucky bluegrass cultivars, accessions, and other Poa species

3 managed under deficit irrigation. Crop Sci. 52:400-407.

4 Dunn, J.H., and K. Diesburg. 2004. Turf management in the transition zone. John Wiley \& Sons

$5 \quad$ Inc., Hoboken, New Jersey.

6 Ebdon, J.S., and K.L. Kopp. 2004. Relationship between water use efficiency, carbon isotope

7 discrimination, and turf performance in genotypes of Kentucky bluegrass during drought.

$8 \quad$ Crop Sci. 44:1754-1762.

9 Ebdon, J.S., and A.M. Petrovic. 1997. Relationship between turfgrass performance and

10 evapotranspiration rate in cultivars of Kentucky bluegrass. J. Turfgrass Manage. 2(2):1-12.

11 Ebdon, J.S., and A.M. Petrovic. 1998. Morphological and growth characteristics of low- and

12 high-water use Kentucky bluegrass cultivars. Crop Sci. 38:143-152.

13 Ebdon, J.S., A.M. Petrovic, and R.W. Zobel. 1998a. Stability of evapotranspiration rates in

14 Kentucky bluegrass cultivars across low and high evaporative environments. Crop Sci.

$15 \quad 38: 135-142$.

16 Ebdon, J.S., A.M. Petrovic, and S.J. Schwager. 1998b. Evaluation of discriminate analysis in 17 identification of low- and high-water use Kentucky bluegrass cultivars. Crop Sci. 38:152$18 \quad 157$.

19 Fagerness, M.J. 2001. Watering your lawn. Kansas State University, January.

$20 \mathrm{Fu}$, J., J. Fry, and B. Huang. 2004. Minimum water requirements of four turfgrasses in the 21 transition zone. HortScience 39:1740-1744.

22 Gibeault, V.A., J.L. Meyer, V.B. Younger, and S.T. Cockerham. 1985. Irrigation of turfgrass 23 below replacement of evapotranspiration as a means of water conservation: Performance of 
1 commonly used turfgrasses. p. 347-56. In F. Lemaire, ed., Proc. Int. Turfgrass Res. Conf., $5^{\text {th }}$,

2 Avignon. 1-5 July 1985. INRA Publ., Versailles.

3 Keeley, S.J., and A.J. Koski. 2001. Dehydration avoidance of diverse Poa pratensis cultivars and

$4 \quad$ cultivar groups in a semi-arid climate. Intl. Turf. Soc. 9:311-316.

5 Kraft, R.W., and S.J. Keeley. 2005. Evaluation of improved Poa pratensis cultivars for transition

$6 \quad$ zone fairway use. Intl. Turf. Soc. 10:368-372.

7 Lyman, G.T., C.S. Throssell, M.E. Johnson, G.A. Stacey, and C.D. Brown. 2007. Golf course

8 profile describes turfgrass, landscape and environmental stewardship features. Online.

$9 \quad$ Applied Turfgrass Science doi:10.1094/ATS-2007-1107-07-RS.

10 Merewitz, E., W. Meyer, S.A. Bonos, and B. Huang. 2010. Drought stress responses and

11 recovery of Texas x Kentucky bluegrass genotypes in temperate climate conditions. Agron. J.

$12 \quad$ 102:258-268.

13 Milesi, C, S.W. Running, C.D. Elvidge, J.B. Dietz, B.T. Tuttle, and R.R. Nemani. 2005.

14 Mapping and modeling the biogeochemical cycling of turfgrasses in the United States.

15 Environ. Manage. 36:426-438.

16 Minner, D. 1984. Cool season turfgrass quality as related to evapotranspiration and drought.

17 Ph.D. dissertation, Colorado State Univ., Fort Collins, CO.

18 Morris, K.N. 2000. Guidelines for using NTEP trial data. Golf Course Manage. 68:64-69.

19 Murphy, J.A., S. Bonos, and P. Perdomo. 1997. Classification of Poa pratensis genotypes.

20 International Turfgrass Society Research Journal 8:1176-1183.

21 National Turfgrass Evaluation Program. 2001. 1995 national Ky. bluegrass test. Rep. 1996-2000

22 Data Final report. NTEP, Beltsville, Maryland. 
1 National Turfgrass Evaluation Program. 2006. 2000 national Ky. bluegrass test. Rep. 2001-05

2 Data Final report. NTEP, Beltsville, Maryland.

3 Richardson, M.D., D.E. Karcher, K. Hignight, and D. Rush. 2008. Drought tolerance and rooting

4 capacity of Kentucky bluegrass cultivars. Crop Sci 48:2429-2436.

5 Richardson, M.D., D.E. Karcher, K. Hignight, and D. Rush. 2009. Drought tolerance of

$6 \quad$ Kentucky bluegrass and hybrid bluegrass cultivars [Online]. Applied Turfgrass Science

$7 \quad 10: 03042009$.

8 SAS Institute Inc. 2002. User installation guide for the SAS system, version 9 for Microsoft

$9 \quad$ Windows. SAS Institute, Cary, NC.

10 Shearman, R.C. 1986. Kentucky bluegrass cultivar evapotranspiration rates. HortScience 21:45511457.

12 Skogley, C.R., and C.D. Sawyer. 1992. Field research. p. 589-614. In A. Waddington (ed.)

13 Turfgrass. 32nd ed. ASA, CSA, SSSA, Madison, WI.

14 Steinegger, D.H., R.C. Shearman, T.P. Riordan, and E.J. Kinbacher. 1980. A comparison of

15 water use rates for Kentucky bluegrass. HortScience 15:396.

16 Su, K., D.J. Bremer, S.J. Keeley, and J.D. Fry. 2007. Effects of high temperature and drought on

17 a hybrid bluegrass compared with Kentucky bluegrass and tall fescue. Crop Sci. 47:2152-

182161.

19 Su, K., D.J. Bremer, S.J. Keeley, and J.D. Fry. 2008. Rooting characteristics and canopy

20 responses to drought of turfgrasses including hybrid bluegrasses. Agron. J. 100:949-956.

21 Su, K., D.J. Bremer, S.J. Keeley, and J.D. Fry. 2009. Mowing and drought effects on a hybrid

22 bluegrass compared with a Kentucky bluegrass. Int. Turf. Soc. Res. J. 11:871-882. 
1 Suplick-Ploense, M.R., and Y. Qian. 2005. Evapotranspiration, rooting characteristics, and

2 dehydration avoidance: Comparisons between hybrid bluegrass and Kentucky bluegrass. Int.

3 Turf. Soc. Res. J. 10:891-898.

4 Turgeon, A.J. (ed.) 2002. Turfgrass management. 6th ed. Prentice Hall, Englewood Cliffs, NJ. 


\section{$1 \quad$ List of Figures}

2 Figure 1. Visual quality of the six Kentucky bluegrass groups with three or more entries during 32007 (A) and 2009 (B). Data are presented in 10-d averages to illustrate seasonal trends. Error 4 bars represent standard errors.

6 Figure 2. Water applied to Kentucky bluegrass cultivars and hybrid bluegrasses versus average

7 visual quality ratings on a 1-9 scale with $9=$ optimum and $1=$ brown turf. Data were averaged over

8 the periods 19 June to 1 Oct. 2007 and 22 June to 7 Oct. 2009. 
1 Table 1. Phenotypic types and cultivars of Kentucky bluegrasses and hybrid bluegrasses.

\begin{tabular}{|c|c|c|c|}
\hline Type $^{\dagger}$ & Cultivar & Type & Cultivar \\
\hline \multirow[t]{2}{*}{ Compact America } & \multirow{2}{*}{$\begin{array}{l}\text { Langara } \\
\text { Bedazzled } \\
\text { Apollo } \\
\text { Unique } \\
\text { Kingfisher }\end{array}$} & Common & $\begin{array}{l}\text { Kenblue } \\
\text { Wellington } \\
\text { Park }\end{array}$ \\
\hline & & \multirow[t]{2}{*}{ Compact } & $\begin{array}{l}\text { Diva } \\
\text { Skye }\end{array}$ \\
\hline \multirow[t]{3}{*}{ Mid-Atlantic } & \multirow{3}{*}{$\begin{array}{l}\text { Eagleton } \\
\text { Preakness } \\
\text { Cabernet }\end{array}$} & & Moonlight \\
\hline & & Julia & Julia \\
\hline & & \multirow{2}{*}{ BVMG } & Baron \\
\hline \multirow[t]{3}{*}{ Compact Midnight } & \multirow{3}{*}{$\begin{array}{l}\text { Midnight } \\
\text { Midnight II } \\
\text { Blue Velvet } \\
\text { Nu Destiny } \\
\text { Award }\end{array}$} & & $\begin{array}{l}\text { Envicta } \\
\text { Abbey }\end{array}$ \\
\hline & & Shamrock & Shamrock \\
\hline & & European $^{\ddagger}$ & $\begin{array}{l}\text { Blue Knight } \\
\text { Bartitia }\end{array}$ \\
\hline Aggressive & $\begin{array}{l}\text { Limousine } \\
\text { Touchdown }\end{array}$ & Hybrid Bluegrasses & $\begin{array}{l}\text { Thermal Blue Blaze } \\
\text { Longhorn }\end{array}$ \\
\hline
\end{tabular}

$2{ }^{\dagger}$ Kentucky bluegrass classification types as described in Bonos et al., 2000.

$3 \ddagger$ Blue Knight and Bartitia have since been reclassified as "Other Type” (Brooks Gould, 2004). 
1 Table 2. Water applied and days to wilt between irrigations of Kentucky bluegrass cultivars and 2 hybrid bluegrasses, averaged over the periods 19 June to 1 Oct. 2007 and 22 June to 7 Oct. 2009, 3 at Manhattan, KS.

\begin{tabular}{|c|c|c|c|c|c|}
\hline Cultivar & \multicolumn{2}{|c|}{ Water Applied (cm) } & Cultivar & \multicolumn{2}{|c|}{ Days to Wilt } \\
\hline Kenblue & 44.9 & $\mathrm{a}^{\dagger}$ & Cabernet & 13.1 & $\mathrm{a}$ \\
\hline Blue Knight & 42.3 & $\mathrm{ab}$ & Bedazzled & 12.4 & $\mathrm{ab}$ \\
\hline Wellington & 41.9 & abc & Unique & 12.1 & $a b$ \\
\hline Moonlight & 38.9 & abcd & Apollo & 11.9 & $\mathrm{abc}$ \\
\hline Baron & 38.5 & abcde & Julia & 11.6 & abcd \\
\hline Diva & 38.1 & abcdef & Preakness & 11.2 & abcde \\
\hline Midnight II & 36.4 & abcdefg & Limousine & 10.2 & bcde \\
\hline Touchdown & 36.0 & abcdefg & Abbey & 9.9 & bcdefg \\
\hline Shamrock & 35.6 & abcdefg & Eagleton & 9.8 & bcdefgh \\
\hline Blue Velvet & 35.1 & abcdefg & Envicta & 9.6 & bcdefgh \\
\hline Nu Destiny & 33.9 & bcdefgh & Kingfisher & 9.2 & cdefghi \\
\hline Award & 33.4 & bcedfgh & Thermal Blue Blaze & 9.0 & cdefghi \\
\hline Langara & 33.4 & bcedfgh & Park & 9.0 & defghi \\
\hline Park & 33.4 & bcedfgh & Bartitia & 8.9 & defghi \\
\hline Longhorn & 33.4 & bcedfgh & Skye & 8.8 & defghi \\
\hline Skye & 32.2 & cdefghi & Longhorn & 8.8 & defghi \\
\hline Midnight & 31.8 & defghi & Midnight & 8.7 & efghi \\
\hline Thermal Blue Blaze & 31.3 & defghi & Langara & 8.5 & efghi \\
\hline Eagleton & 31.3 & defghi & Award & 8.3 & fghi \\
\hline Bartitia & 30.9 & defghi & Shamrock & 8.3 & fghi \\
\hline Kingfisher & 30.9 & defghi & Nu Destiny & 8.2 & fghi \\
\hline Limousine & 30.5 & defghi & Blue Velvet & 8.0 & fghi \\
\hline Envicta & 28.8 & efghi & Midnight II & 8.0 & fghi \\
\hline Julia & 28.4 & fghi & Touchdown & 7.9 & fghi \\
\hline Abbey & 27.9 & ghi & Diva & 7.8 & fghi \\
\hline Preakness & 27.1 & ghi & Baron & 7.4 & fghi \\
\hline Unique & 25.0 & hi & Moonlight & 7.1 & ghi \\
\hline Cabernet & 24.6 & hi & Wellington & 7.0 & hi \\
\hline Apollo & 24.1 & hi & Blue Knight & 6.5 & $\mathrm{i}$ \\
\hline Bedazzled & 23.3 & $\mathrm{i}$ & Kenblue & 6.4 & $\mathrm{i}$ \\
\hline
\end{tabular}


1 Table 3. Water applied, days to wilt between irrigations, and orthogonal contrast statements

2 among Kentucky bluegrass groups, averaged over the periods 19 June to 1 Oct. 2007 and 22 June 3 to 7 Oct. 2009.

4

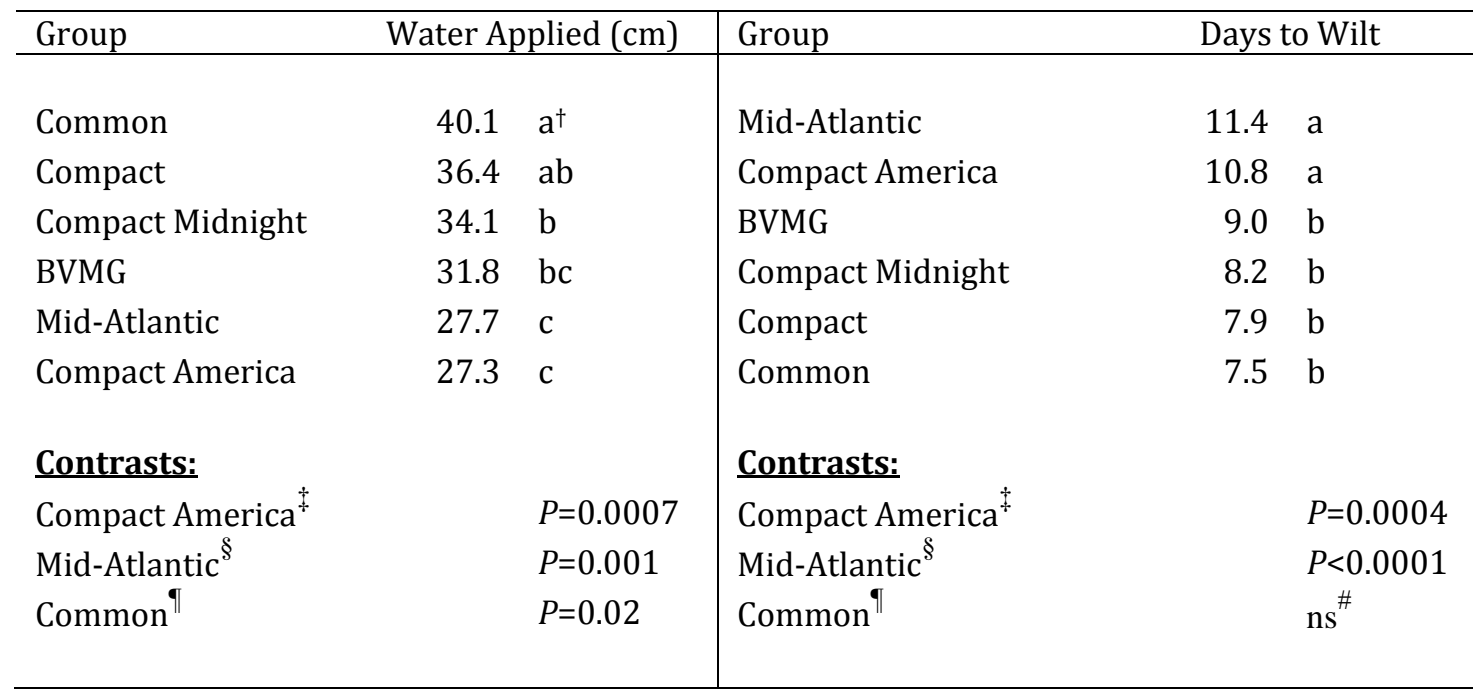

$5{ }^{\dagger}$ Means followed by differing letters within each column (Water Applied and Days to Wilt) are significantly 6 different $(P=0.05)$.

$7 \quad{ }^{\ddagger}$ Contrasted with all other phenotypic groups that had three or more entries.

$8 \quad \S$ Contrasted with other groups that had three or more entries, excluding Compact America.

9 "Contrasted with other groups that had three or more entries, excluding Compact America and Mid-Atlantic.

$10 \quad$ \# Not significant $(P=0.05)$. 
1 Table 4. Days until visual quality of each cultivar declined to less than six and visual quality 2 among Kentucky bluegrass groups and hybrid bluegrasses, averaged over the periods 19 June to 31 Oct. 2007 and 22 June to 7 Oct. 2009.

\begin{tabular}{|c|c|c|c|c|c|}
\hline Cultivar & Days unt & I Quality $<6^{\dagger}$ & Cultivar & Visua & Quality \\
\hline Blue Velvet & 44.8 & $a^{\ddagger}$ & Blue Velvet & 6.17 & $\mathrm{a}$ \\
\hline Award & 43.1 & $\mathrm{a}$ & Bartitia & 6.13 & $\mathrm{a}$ \\
\hline Midnight & 41.7 & $\mathrm{a}$ & Preakness & 6.04 & $a b$ \\
\hline Cabernet & 41.7 & a & Nu Destiny & 6.03 & $a b$ \\
\hline Unique & 36.7 & $\mathrm{ab}$ & Limousine & 6.01 & abc \\
\hline Nu Destiny & 36.0 & $\mathrm{ab}$ & Envicta & 5.99 & abc \\
\hline Bedazzled & 35.3 & $\mathrm{abc}$ & Midnight & 5.97 & abc \\
\hline Preakness & 35.2 & abc & Touchdown & 5.96 & abc \\
\hline Bartitia & 34.8 & abcd & Julia & 5.91 & $\mathrm{abc}$ \\
\hline Langara & 34.3 & abcd & Award & 5.91 & abc \\
\hline Abbey & 33.6 & abcd & Bedazzled & 5.87 & $\mathrm{abc}$ \\
\hline Moonlight & 33.5 & abcd & Skye & 5.87 & $\mathrm{abc}$ \\
\hline Apollo & 32.8 & abcd & Unique & 5.86 & abc \\
\hline Kingfisher & 31.4 & abcd & Kingfisher & 5.86 & $\mathrm{abc}$ \\
\hline Limousine & 31.0 & abcd & Thermal Blue Blaze & 5.85 & $\mathrm{abc}$ \\
\hline Skye & 30.4 & abcd & Blue Knight & 5.84 & abc \\
\hline Envicta & 30.1 & abcde & Abbey & 5.82 & abc \\
\hline Julia & 28.9 & abcdef & Langara & 5.81 & $\mathrm{abc}$ \\
\hline Eagleton & 28.3 & abcdef & Moonlight & 5.77 & abc \\
\hline Diva & 27.6 & abcdef & Cabernet & 5.74 & abcd \\
\hline Thermal Blue Blaze & 25.9 & abcdef & Longhorn & 5.73 & abcd \\
\hline Blue Knight & 25.6 & abcdef & Apollo & 5.66 & abcd \\
\hline Touchdown & 25.2 & abcdef & Eagleton & 5.63 & abcd \\
\hline Shamrock & 19.9 & bcdef & Shamrock & 5.59 & abcde \\
\hline Midnight II & 19.6 & bcdef & Baron & 5.57 & abcde \\
\hline Longhorn & 17.8 & bcdef & Diva & 5.48 & bcde \\
\hline Park & 14.2 & cdef & Midnight II & 5.47 & bcde \\
\hline Baron & 13.8 & def & Wellington & 5.40 & cde \\
\hline Wellington & 8.8 & ef & Park & 5.13 & de \\
\hline Kenblue & 8.1 & $\mathrm{f}$ & Kenblue & 4.98 & e \\
\hline
\end{tabular}

$5 \quad{ }^{\dagger}$ After visual quality was less than six for three days, which were rarely consecutive.

$6 \quad{ }^{\ddagger}$ Means followed by differing letters within each column (Days until Quality $<6$ and Visual Quality) are 7 significantly different $(P=0.05)$. 
1 Table 5. Days until visual quality of each cultivar declined to less than six, visual quality, and 2 orthogonal contrasts among Kentucky bluegrass groups, averaged over the periods 19 June to 1 3 Oct. 2007 and 22 June to 7 Oct. 2009.

4

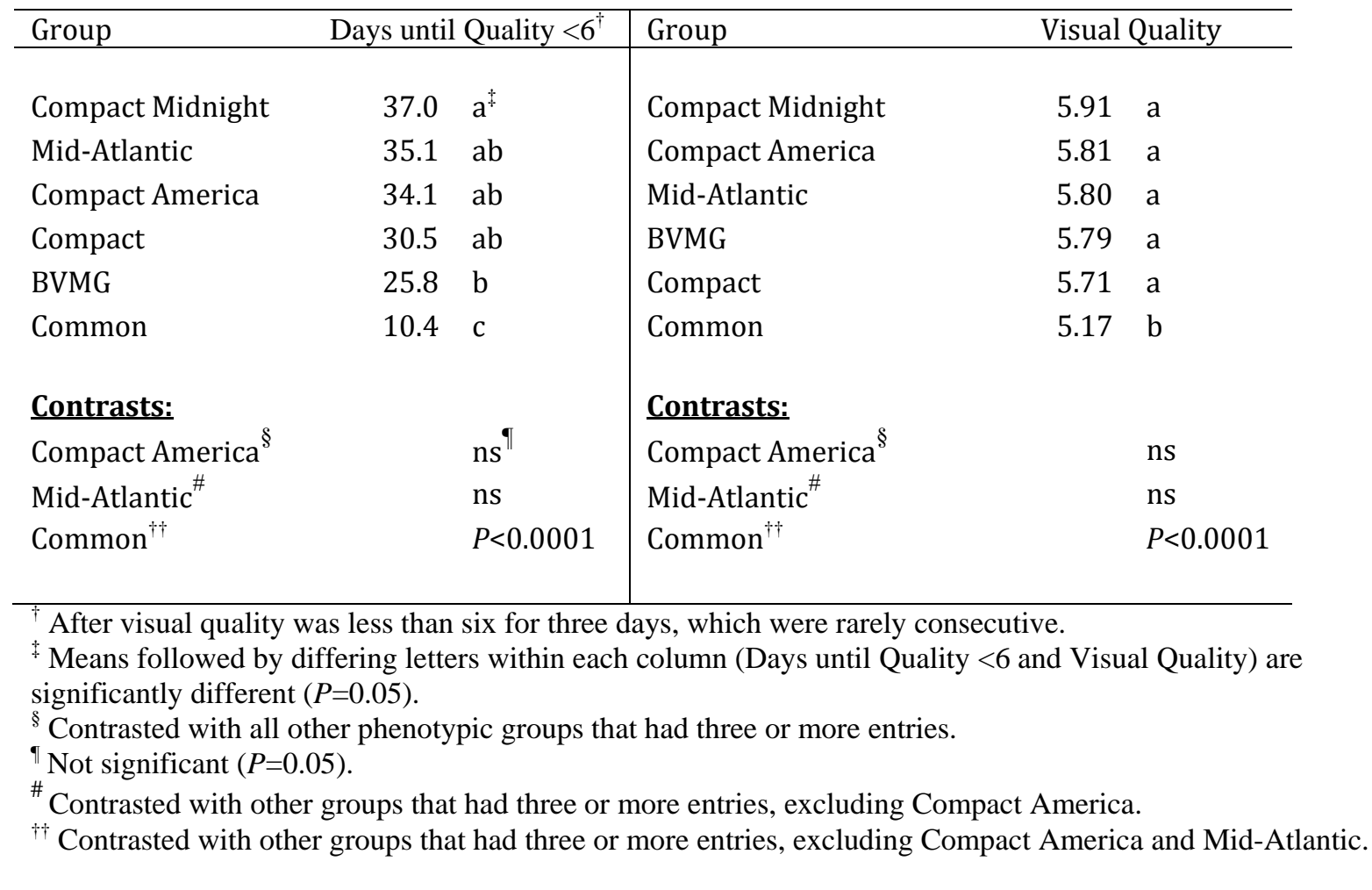



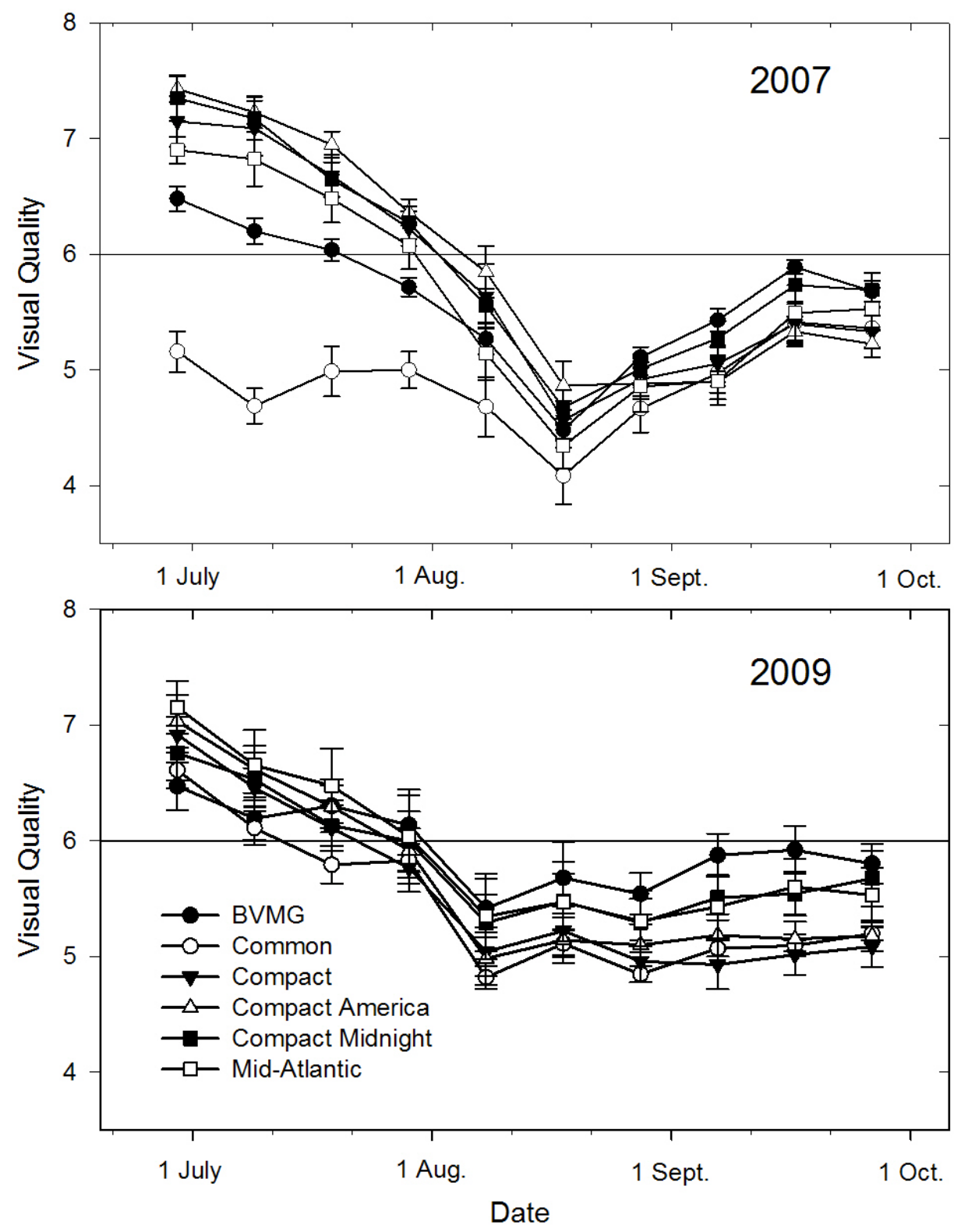

Figure 1 


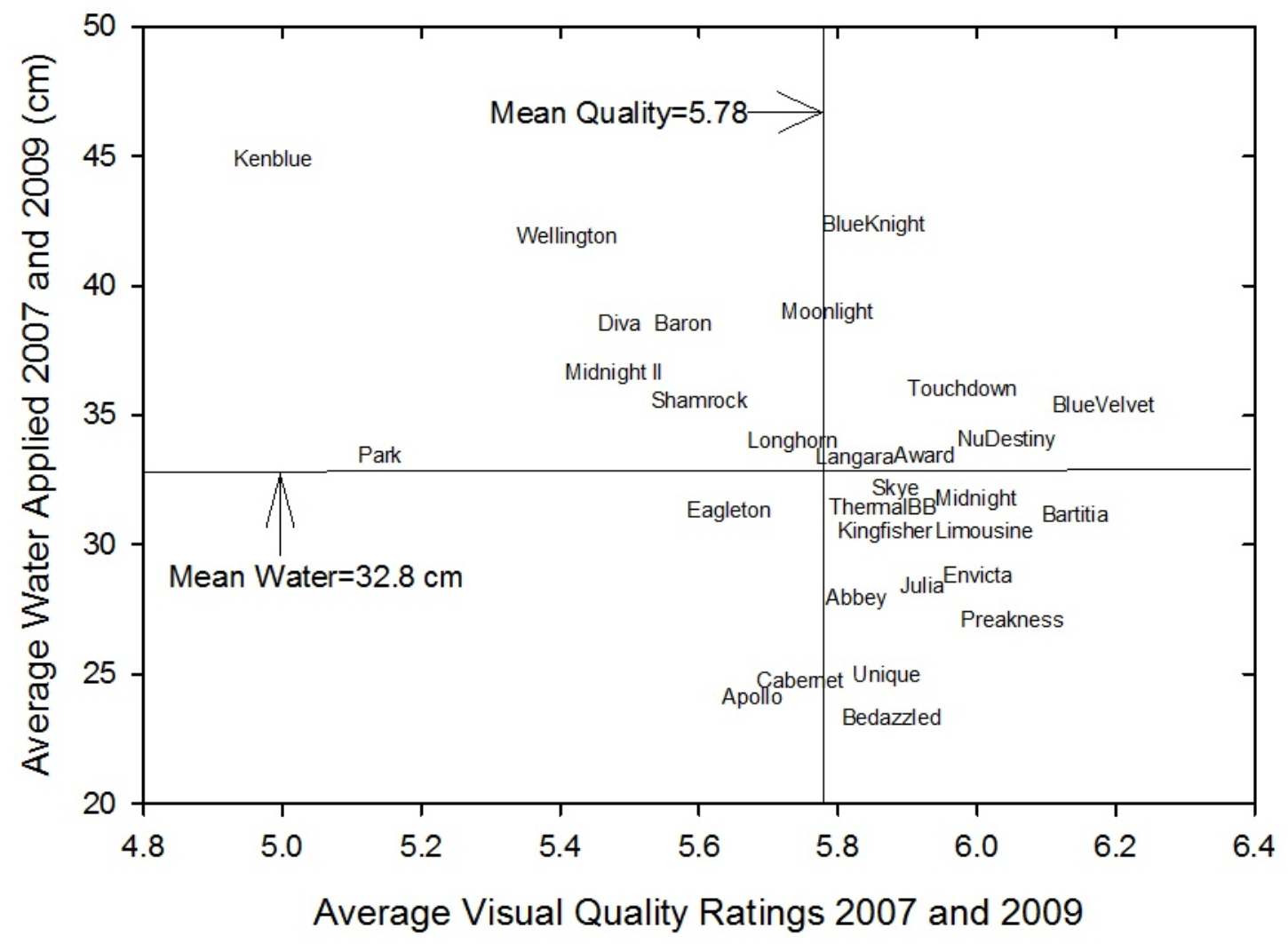

1

Figure 2 